\title{
Vurdering for læring - en trojansk hest i skolen?
}

Tidsskriftet Sakprosa

Bind 10, Nummer 2

(C) 2018

10.5617/sakprosa.6o23 


\section{Sammendrag}

Artikkelen undersøker hvordan gevinster ved evaluering og vurdering framstilles i en autoritativ OECD-tekst som evaluerer norsk skole.

Undersøkelsen benytter kritisk diskursanalyse som metodisk utgangspunkt og trekker fram tre ulike praksiser knyttet til virksomheten i skolen i denne sammenhengen: Utdanningspolitisk forvaltningspraksis, pedagogisk praksis og forskningspraksis. Analysen viser at tekstens rekkevidde og utøvelse av autoritet går ut over den utdanningspolitiske forvaltningspraksis den er del av, og også griper inn i skolens pedagogiske praksis. Dette skjer ved å skape legitimitet gjennom forskningspraksis, knyttet til fenomenet vurdering for læring. Drøftingen handler om i hvilken grad evalueringstekster mer allment bidrar til å endre handlingsrommet til aktørene i skolesystemet, og om hvilke muligheter aktørene som opererer innenfor den pedagogiske praksis, har til å bevare sin autonomi under påvirkning av resultat- og målstyringstenkningen som preger New Public Management-paradigmet.

\section{Abstract}

This article investigates how benefits of evaluation and assessment are portrayed in a premise providing OECD-text evaluating the Norwegian school system. The investigation employs Critical Discourse Analysis as methodological stance, emphasising three different practices associated with the operation of schooling: Educational policy-administration practice, pedagogical practice, and research practice. The analysis finds that the scope and authority of the text is expanded from its rooting in the educational policy-administration practice, interfering with pedagogical practice. This process is legitimised by research practice's affiliation with the phenomenon assessment for learning. The final discussion deals with to which extent evaluation texts in general constrains school professionals' vocational movement. It also investigates which possibilities actors operating inside 
pedagogical practice have protecting their autonomy influenced by resultsbased accountability and management by objectives, originating from the New Public Management-paradigm.

Nøkkelord: Evaluering, vurdering for læring, kritisk diskursanalyse, OECD, NPM, skolestyring, pedagogisk praksis.

\section{Om forfatteren:}

Nils Rune Birkeland er ansatt ved Universitet i Agder som førstelektor ved Institutt for nordisk og mediefag, Fakultetet for humaniora og pedagogikk. 


\section{Vurdering for læring - en trojansk hest i skolen?}

\section{Innledning}

Evaluering og vurdering er fenomener med en tydelig tekstlig komponent som, parallelt med innfasingen og videreutviklingen av læreplanreformen Kunnskapsløftet (LKo6), synes å ha blitt stadig mer omseggripende i norsk skole. Denne komponenten kan avleses i dokumenter både rettet mot og produsert av virksomheter på flere nivåer i skolesystemet. Et perspektiv dreier seg om evalueringstekster som funksjonelle verktøy brukt til kartlegging i selve opplæringssituasjonen - som utgangspunkt for pedagogenes egne prioriteringer og for tiltak i kontakten med elevene og foreldrene. Et annet perspektiv handler om evalueringstekster som kartlegger med formål om bedret offentlig innsyn i skolehverdagen - som utgangspunkt for styringstiltak og prioriteringer på systemnivå. I begge tilfeller er målet å heve kvaliteten i elevenes læring, eller slik tidligere utdanningsminister Gudmund Hernes treffende uttrykte det i offentlige utredninger allerede på slutten av 1980tallet: «Utfordringen for norsk kunnskapspolitikk er at landet ikke får nok kompetanse ut av befolkningens talent» (NOU 1988:28, s. 7).

Med utgangspunkt i kritisk diskursanalyse (KDA) som samfunnsorientert tekstforskningstradisjon vil enkelte evalueringstekster kunne oppfattes som særlig autoritative. Slike tekster forbinder ulike praksiser innenfor skolefeltet i teksthendelser som kan skape ringvirkninger utenfor en mer avgrenset situasjonskontekst. Teksten som analyseres i denne artikkelen, kapittelet «Konklusjoner og anbefalinger» i OECDs gjennomgang av evaluering og vurdering innen utdanning: Norge (Nusche, Earl, Maxwell \& Shewbridge, 2012, s. 129-141), kan antas å være eksempel på dette. Isolert sett inngår den i en internasjonal evalueringspraksis, men de senere årene har OECD (Organisasjonen for økonomisk samarbeid og utvikling), blant annet gjennom sitt PISA-engasjement (Programme for International Student Assessment), 
vist stadig sterkere interesse også for den mer konkrete pedagogiske virksomheten i skolen.

Artikkelen undersøker hvordan gevinster ved evaluering av vurdering i skolen framstilles i den nevnte OECD-teksten. Dette medfører også et spørsmål om hvorvidt tekstens rekkevidde og utøvelse av autoritet primært omfatter styringspraksis eller den pedagogiske praksis. I en kritisk diskursanalyse er det sentrale perspektivet likevel hvilke muligheter og begrensninger undersøkelsen avdekker for de ulike aktørene i skolen som virksomhetsområde i samfunnet. Dette blir også utgangspunkt for en drøfting av evalueringsteksters funksjon, både i styringstiltak og for læringsaktiviteter i dagens skole.

\section{Teoretisk bakgrunn: Motiver og praksis innenfor vurderingsfeltet}

Professor i pedagogikk Astrid Eggen etterlyser en ramme for analyse av interaksjonen mellom ulike praksiser innenfor vurderingsfeltet, både utdanningspolitisk forvaltningspraksis, undervisningspraksis og forskningspraksis (2007, s. 151-152). Avhengig av praksis, hevder hun, vil det være en veksling mellom ulike motiver. Som bakgrunn for tekstanalysen vil jeg her først presentere noen teoretiske rammevilkår for hver av disse praksisene.

\section{Utdanningspolitisk forvaltningspraksis}

I Norge skjer det i tiden rundt årtusenskiftet en endring i, og ikke minst en forskyvning av, ordbruken i offentlige utredninger og styringsdokumenter om kvalitet i skole og utdanning (Utdannings- og forskningsdepartementet, 1990, 2004; NOU 2002:10; NOU 2003:16). Kvalitet blir en standard som aktørene i skolen må forholde seg til. Distinksjonene ressurs (input), prosess og resultat (output) holdes her fram som ulike kvalitetsdimensjoner. Tendensen er at ressurs og prosess gis en fasiliterende funksjon i forhold til resultat, som făr 
en sterkere betydning som overordnet styringsprinsipp. Dette benevnes som «kvalitetshierarkiet», og språkbruken indikerer en bevegelse bort fra sentralisert styring av ressurser og prosesser i skolen til sentralisert kontroll av output og styring etter resultater (Langfeldt, Elstad \& Hopmann, 2008). Dette fokuset på resultatstyring kan også betraktes som en konsekvens av et mer overordnet paradigme for organisering av offentlig virksomhet: New Public Management (NPM), se også Gunhild Kvåles artikkel i dette nummeret.

Under NPM-paradigmet opptrer resultatstyring ikke nødvendigvis alene, men parallelt med målstyring. Målstyring har i offentlig virksomhet handlet om hvordan generelle mål formulert i toppen av styringshierarkiet tolkes, tilpasses og konkretiseres av aktørene på nivåene under. Stortingsmelding nr. 37 (1990-1991) Om organisering og styring i utdanningssektoren (Kirke-, utdannings- og forskningdepartementet, 1991) relaterer modellen til virksomheten i skolen, hvor den nasjonale læreplanen (input) presisert og konkretisert i lokalt læreplanarbeid (prosess) har fungert på denne måten. Aktørene tenkes slik å få et eierforhold til egenformulerte mål i et tillitsbasert system med de involverte profesjonsgruppene som kvalitetsgarantister. Under innflytelse av NPM svekkes denne tilliten til profesjonsgruppenes fagfellesskap og erstattes med krav om dokumentasjon overfor eksterne aktører, det være seg høyere opp i styringshierarkiet eller overfor et marked av brukere (Burke, 2005; Hood, 2002). Slik kommer fokus på resultat i forgrunnen på alle nivåer i virksomheten, men samtidig videreføres målstyringen siden formulering av mål angir en standard resultatene kan vurderes i forhold til.

Endringen medfører at de som er involvert, kan stilles til ansvar for dokumentasjon og oppfølging av resultater overfor eksterne aktører, ikke bare for prosessen med utarbeidelse av mål og for eierforholdet til disse innenfor et profesjonsfellesskap. Robert Behn (2001) hevder det i utgangspunktet er lettere å etablere systemer som ansvarliggjør aktører med hensyn til input og 
prosess enn i forhold til resultat, og benevner dette som «accountabilitybiaset». I relasjonen mellom ansvarsstiller og ansvarshaver kan altså forventninger knyttet til utnyttelsen av ressurser, tolkning av styringsdokumenter eller bruken av bestemte framgangsmåter lettere forankres i praksiser som kontrolleres av aktørene selv. Dette står i motsetning til forventninger knyttet til output/prestasjoner, som kan være resultat av mange ulike faktorer utenfor aktørenes kontroll, noe som forsterkes dersom ansvarsstiller ikke selv er involvert i virksomheten. De internasjonale PISA-, PIRLS-, og TIMSS-testene ${ }^{1}$ samt nasjonale prøver i skolen kan oppfattes som eksempel på slik kontroll av output. Dette er evalueringsverktøy som skal gi informasjon til politiske myndigheter, beslutningstakere i skolesystemet og til aktører ellers i samfunnet (f.eks. mediene og elevenes foresatte) som grunnlag for framtidige prioriteringer, styringstiltak og (for)brukervalg. Om slik resultatbasert ansvarliggjøring skal fungere og dreie praksis i ønsket retning, kreves en relativt sterk maktutøvelse fra myndighetenes side, og skal dette skje på en legitim måte overfor de involverte aktørene, kreves i tillegg en smart strategi i utnyttelsen av de ulike styringsvirkemidlene.

\section{Pedagogisk praksis}

Det er altså ikke gitt at den pedagogiske praksisen i skolen beveger seg i samme retning som den utdanningspolitiske forvaltningspraksis skulle tilsi. Læringsarbeidet vil helt klart kunne bli påvirket av økende resultatfokus, for eksempel gjennom nasjonale prøver og andre typer evalueringsverktøy som skal avgi styringsinformasjon til myndigheter og offentlighet, men spørsmålet er om endringen blir som ønsket. Campbells lov sier at jo større sosiale konsekvenser (belønning eller sanksjoner) som knyttes til en sosial indikator,

\footnotetext{
${ }^{1}$ Programme for International Student Assessment, Progress in Reading Literacy Study og Trends in International Mathematics and Science Study.
} 
desto større er risikoen for at både indikatoren i seg selv og de sosiale prosessene den har til hensikt å måle, blir manipulert (Campbell, 1976). I dette ligger en mulighet for at læringsarbeidet i skolen som sosial praksis blir negativt påvirket, for eksempel ved innsnevring av læringsmål og ensretting av læringsaktiviteter. En annen konsekvens av dette er at den styringsinformasjonen som kommer ut av slike evalueringer, kan bli mindre valid. I hvor stor grad slike effekter opptrer i det norske skolesystemet, er vanskelig å si. Bortsett fra den bebreidelsesmanøvreringen som foregår i forbindelse med medienes offentliggjøring av resultater på nasjonale prøver (Elstad, 2010; Langfeldt \& Birkeland, 2010), er konsekvensene for de involverte aktørene fortsatt ikke så store. Videre gir de overordnede kompetansemålene i læreplanen LKo6 lærerne, i alle fall i utgangspunktet, større frihet til selv å kunne styre både innholdet og arbeidsmåtene i læringsarbeidet. Om man ser det nye fokuset på kompetansemål isolert, forpliktes lærerne likevel langt sterkere på resultater som begrunnelse for sin virksomhet. Det avgjørende spørsmålet blir da hvordan lærerne i skolen forvalter dette resultatfokuset. Det vil si om det er selve vurderingsresultatet som får verdi, som resultatkvalitet, eller om det er fokuset på resultater i seg selv som blir norm for pedagogisk praksis gjennom en slags fornyet forståelse for prosesskvalitet. Her ligger en viktig nyanseforskjell.

\section{Forskningspraksis}

Selv om «evaluering» og «vurdering» etymologisk har samme meningsinnhold, har det i de senere årene skjedd en utdifferensiering i begrepsbruken. I Norge brukes nå nesten utelukkende «vurdering» om det som uttrykker kvalitet på eller grad av måloppnåelse i elevers skolearbeid (Engh, 2011, s. 23). I nyere britisk forskningslitteratur benyttes ikke «evaluation», kun «assessment», om elevers skolearbeider, og britiske forskere tilknyttet Assessment Reform Group har gjennom sine publikasjoner hatt stor innflytelse på prioriteringene til det norske utdanningsdirektoratet 
(ibid.). De hyppig siterte artiklene «Inside the black box» (Black \& Wiliam, 1998) og «Working inside the black box» (Black, Harrison, Lee \& Wiliam, 2004) kan synes å imøtekomme legitimeringsbehovet som har oppstått når nye ideer for styring av skolevirksomheten, gjennom et stadig sterkere fokus på resultatkvalitet, utfordrer accountability-biaset. Titlene henspiller på at den utdanningspolitiske forvaltningspraksis, med sitt forsterkede fokus på ansvarliggjøring og resultat, er blind for det som skjer i klasserommet. I slik forvaltningspraksis betraktes skoleresultater som summen av de rammevilkår og ressurser som puttes inn, og det ytre press som tilføres skolen gjennom ansvarliggjøring knyttet til høye standarder. Løsningen som tilbys, er vurdering for læring. Her åpnes klasserommet opp, og den pedagogiske prosessen forutsettes på en måte å internalisere den autoritative kulturen resultatstyringen representerer. I lys av læreplanenes fokus på kompetansemål ligger det nettopp her en mulighet for lærerne til å ta tilbake noe av kontrollen: Ved å la resultatvurderinger både bli begrunnelse for og kjennetegnet på egen praksis, vil man i mindre grad oppleve å bli styrt av resultatevalueringer foretatt av eksterne aktører.

John Hattie, som gjennom sine publikasjoner og i likhet med Assessment Reform Group også har øvet stor innflytelse på begrepsapparatet og fagdebatten om kvaliteten i norsk skole, har bidradd til å forsterke fokuset på vurdering for læring ved å påvise positive effekter på elevers læringsutbytte (Hattie \& Timperley, 2007). I skolens eget praksisspråk assosieres vurdering for læring nå med underveisvurdering, formativ vurdering og uformell vurdering, i motsetning til vurdering av læring, som assosieres med sluttvurdering, summativ vurdering og formell vurdering. Vurdering av læring i den pedagogiske praksis framstår på denne måten som ekvivalenten til ekstern evaluering av resultatkvalitet i den utdanningspolitiske forvaltningspraksis, som mange lærere opplever som fremmedgjørende. Det er altså ikke resultatstyringens «black boxing», gjennom de formaliserte evalueringenes resultatframvisninger og ansvarliggjøring basert på dem, som gir gevinst i seg 
selv. Det er nettopp ved å la vurdering overta styringen av skolens pedagogiske praksis, gjennom en slags vurdering som læring, at gevinsten skal kunne hentes ut.

\section{Oppsummering}

Presentasjonen av de tre praksisene innenfor vurderingsfeltet sier noe både om kontinuitet, slektskap og regi. Kontinuiteten ligger i måten den alt etablerte målstyringen i den utdanningspolitiske forvaltningspraksis integreres i resultatstyringstankegangen. Slektskapet handler om den felles bevegelsen, eventuelt hegemoniet, som resultatfokuset er i ferd med å etablere som begrunnelse for aktørenes virksomhet på tvers av praksiser. Regi handler til slutt om en kronologi der det først oppstår utfordringer ved økt fokus på resultatstyring og resultatbasert ansvarliggjøring: accountability-biaset i den utdanningspolitiske forvaltningspraksis og Campbells lov i den pedagogiske praksis. En løsningsretning pekes ut allerede i den omtalte nyanseforskjellen i forståelsen av hva slags status vurdering skal ha i pedagogisk praksis. Selve løsningen blir så til slutt å finne i forskningspraksis, som begrunner hvorfor vurdering for læring kan framstå som mulighet.

\section{Kritisk diskursanalyse}

Begrepsapparatet som benyttes og rammeverket for tekstanalysen i denne artikkelen er inspirert av KDA, slik den utlegges i Norman Faircloughs Analysing discourse (2003) og hos Joar Skrede (2017). Fairclough opererer med tre analysenivåer som kan være egnet til å beskrive samspill mellom ulike praksiser innenfor evaluerings-/vurderingsfeltet i skolen som samfunnsinstitusjon. Sosial struktur handler om samfunnsmessige makroforhold, slik som maktrelasjoner mellom ulike aktører (styringsbetingelser), organisering (byråkrati), økonomiske strukturer (kapitalisme/globalisering). Disse byr både på muligheter og begrensninger for de involverte aktørene, men kommer 
først til syne i sosiale hendelser der konkrete tekster utgjør det språklige/semiotiske elementet. Men det er sosial praksis som etablerer relasjonen mellom slike faktiske begivenheter og den omkringliggende sosiale strukturen. Dette skjer gjennom at visse strukturelle muligheter selekteres og kontrolleres i relativt stabile mønstre.

Hvor dominerende språket er, avhenger både av hvilken type praksis og hvilke sosiale hendelser det er snakk om. Språkets rolle kan antas være stor i den internasjonale utdanningspolitiske forvaltningspraksis undersøkelsens materiale hentes fra. Her er en vesentlig del av samhandlingen mellom aktørene dokumentbasert, det gjelder også for den aktuelle sosiale hendelsen teksten er del av, som isolert sett dreier seg om avlevering av en evalueringsrapport bestilt av norske utdanningsmyndigheter. Men selv ikke i slike tilfeller reduserer KDA sosiale praksiser eller hendelser til språk, anfører bare at disse har en klar semiotisk dimensjon som består av tre elementer: sjanger, diskurser og stil (Skrede, 2017, s. 33). Sjanger handler om tekst som sosial handling, diskurser handler om tekst som virkelighetsrepresentasjon, og stil handler om tekst som avsenderidentifikasjon (Fairclough, 2003). Michael Hallidays (2004) metafunksjoner (tekstuell, ideasjonell og mellompersonlig) kan gjenkjennes her, men inndelingen er ikke helt den samme. Det er de tre elementene som på et overordnet nivå strukturerer tekstanalysen i denne artikkelen. Operasjonaliseringen av disse, som språklige markører i verbalteksten, skjer i metodeavsnittet.

Begrepet «diskursorden» er også sentralt i denne sammenhengen og viser til en viss stabilitet på tvers av sosiale praksiser som gjør at de er gjenkjennelige som noenlunde ordnet (Skrede, 2017, s. 38). En diskursorden knyttet til evalueringstekster i skolen blir da gjenkjennelig rent språklig ved at visse sjangrer, diskurser og stiler kjedes sammen. Bestemte trekk velges ut og andre ekskluderes slik at lingvistisk variasjon kontrolleres og dermed kan gjenkjennes som mønster, det være seg i utdanningspolitisk forvaltningspraksis, i 
pedagogisk praksis eller i forskningspraksis. Det gir dermed mening, slik som her, å analysere en evalueringstekst produsert og sirkulert innenfor én av disse praksisene, som uttrykk for trekk som også kan gjenfinnes i de øvrige praksisene.

\section{Materiale og metode}

Analyseteksten (Nusche et al., 2012, s. 129-141) kan oppfattes som en evalueringstekst innenfor utdanningspolitisk forvaltningspraksis. Den utgjør et kapittel («Konklusjoner og anbefalinger») som summerer opp sentrale momenter i en mer omfattende rapport, OECDs gjennomgang av evaluering og vurdering innen utdanning: Norge, som fungerer som evalueringstekst i streng forstand. Teksten er tilgjengelig via permanent lenke (se litteraturlista). Denne rapporten er igjen del av en serie rapporter om tilsvarende forhold $\mathrm{i}$ flere OECD-land som, i likhet med Norge, har bestilt evalueringen.

Rapporten, opprinnelig skrevet på engelsk, kan slik antas også å være del av en internasjonal tekstpraksis med særegne trekk. Mitt anliggende er ikke å karakterisere denne praksisen i seg selv, på tvers av slike rapporter, men å undersøke hvilke betingelser tekstens framstillingsform etablerer for andre praksiser i det norske skolesystemet. Artikkelens forskningsspørsmål åpner for at teksten også kan ha en styrende funksjon som involverer annen praksis gjennom anbefalingene som gis.

Valget av nettopp denne teksten og dette doble perspektivet kan være påvirket av mine egne fordommer og dermed true gyldigheten i undersøkelsen. Videre kan rollen evaluering og vurdering har i skolesystemet som helhet, tenkes bedre representert, både som styringspådriv og som pedagogisk tiltak. Andre tekster innenfor samme diskursorden, for eksempel slike som sirkulerer i den pedagogiske praksis i skolen, kunne i like stor grad sies å representere «helheten». Når analysen likevel konsentreres om OECD-teksten, handler det både om dens autoritet i seg selv og om språkets dominerende funksjon i 
praksisen den inngår i. Det betyr at en analyse her lettere kan konsentreres om den semiotiske dimensjonen enn tilfellet ville vært for en tekst hentet fra pedagogisk praksis, hvor flere forhold fra den aktuelle situasjonskonteksten må tas hensyn til. En reservasjon for analysen er at jeg ikke problematiserer oversettelsen fra engelsk som mulig feilkilde, men forutsetter at den norske versjonen er tilstrekkelig kvalitetssikret av Utdanningsdirektoratet som ansvarlig utgiver.

Hos Fairclough (2003) fungerer den semiotiske dimensjonen i sosiale hendelser og i sosial praksis som et speilbilde av sosial praksis i det hele tatt. Dette kommer fram i måten han omtaler de tre elementene som henholdsvis «ways of acting», «ways of representing» og «ways of being». Sjanger handler med dette helt overordnet om måter å handle på ved hjelp av verbalspråket eller andre semiotiske systemer. Diskurser handler tilsvarende om måter å henvise til noe på. Til slutt handler stil om måter å stå fram som aktør i den sosiale praksisen på. Tekstanalysen i undersøkelsen avgrenses til utvalgte verbalspråklige markører for disse.

Som uttrykk for sjanger konsentreres analysen om språkhandlinger (Searle, 1969), både de som signaliseres eksplisitt gjennom strukturerende overskrifter, og de som signaliseres gjennom typen emnesetninger. Når det gjelder diskurser, fokuseres det på de mest sentrale referentkjedene i teksten - hvordan disse kan karakteriseres hver for seg, og hvordan de fungerer i forhold til hverandre. Til slutt, som uttrykk for stil, handler det om to aspekter: 1) Tiltalemåte - hvordan tekstens avsender framstiller seg selv i forhold til mottakergruppen -, og 2) påstandssikkerhet - med hvilken sikkerhet tekstens referensielle innhold framstilles (riktighet), og hvilken autoritet som uttrykkes i utsagn som adresserer ulike grupper og praksiser i skolesystemet (viktighet). Fairclough (2003) bruker transitivitet som merkelapp på det første aspektet og modalitet (epistemisk og deontisk) på det andre. 
Måten den semiotiske dimensjonen operasjonaliseres på, som uttrykk både for utdanningspolitisk forvaltningspraksis og for pedagogisk praksis, kan beskyldes for å være lite troverdig. Utvalget av språklige trekk det fokuseres på i analysen, kan kritiseres for å være styrt av en fortolkningsramme som primært tilfredsstiller intensjonen med å gjennomføre undersøkelsen. Slik anklage om «cherry-picking» rettes ofte mot (tekst)kritisk samfunnsforskning (Skrede, 2017, s. 159-160). I presentasjonen av markører på språklige trekk tilstreber jeg å være så transparent som mulig. Dels kartlegges slike trekk gjennom opptelling og sammenlikning av antall forekomster. Til dette formålet er det benyttet søkefunksjonalitet i et standard tekstvisningsprogram (Adobe Reader DC). For sammenlikninger av størrelsesforhold benyttes også khikvadrattest ved enkelte tilfeller (signifikansnivå: $\mathrm{p}<0,05$ for nullhypotesen). I tillegg benyttes kortere teksteksempler til konkretisering. Dette gir likevel rom for tolkning og åpner for at andre «lesere» kan komme fram til andre resultater. I den forbindelse er det viktig å understreke at kritisk diskursanalyse av en tekst som tematiserer styring og pedagogikk i skolesystemet, ikke er en undersøkelse av et absolutt meningsinnhold, men av hvordan bestemte meningspotensialer avgrenses og kan utfoldes innenfor visse sosiale praksiser under gitte strukturelle betingelser. Videre er KDA likevel ikke et nøytralt verktøy, kun med den hensikt å beskrive gjeldende samfunnsforhold gjennom å avdekke utvalgte teksters meningspotensial i ulike omgivelser. Målsettingen med slik analyse er i tillegg, gjennom kritisk tilnærming til bestemte trekk ved samfunnsutviklingen, å vise hvordan en bestemt type ideologisk språkbruk bidrar til å hemme de sosiale aktørenes forståelse for at det finnes alternativer. På denne måten kan en kritisk tilnærming indirekte utfordre språklig ensretting eller selvfølgeliggjøring som bidrar til å etablere, vedlikeholde eller transformere bestemte sosiale maktrelasjoner (Skrede, 2017, s. 27-29). Leseren bør være seg bevisst at analysen i denne artikkelen ikke er noe unntak fra dette. 


\section{Analyse}

Kapittelet har følgende underoverskrifter: «Bakgrunn om utdanningssystemet», «Sterke sider og utfordringer» og «Anbefalinger». Tredelingen gjenspeiler organiseringen av OECD-rapporten som helhet. Samtlige av avsnittene tilordnet underoverskriftene innledes enten med en emnesetning eller et setningsemne med kursivert og uthevet skrifttype, skilt fra den øvrige teksten med omgivende linjer. Til sammen består tekstutdraget av 30 slike avsnitt. Der underoverskriftene består av setningsemner, bidrar de tilhørende avsnittene med nødvendig utfylling av subjekt og verbal, et samspill som gjør at også setningsemnene fungerer som fullverdige emnesetninger.

\section{Sjanger som handlingsmåte}

Teksten oppsummerer OECD-evalueringens funn, men er ikke bare kartlegging i form av tilstandsbeskrivelser. Den kommer også med anbefalinger rettet mot praksis. Dette markeres ikke bare i tittelen, men kommer også tydelig fram i den tredelte tekststrukturen beskrevet ovenfor. Det er bare «Bakgrunn om utdannelsessystemet» som oppfattes som rent deskriptiv. Her fungerer tre av tre setningsemner som konstativer, for eksempel bygges «Vedvarende satsing på å heve kvalitet og likeverd $i$ utdanningen» (s. 129) enkelt ut til en emnesetning med «Norge» som subjekt.

Underoverskriftene (emnesetningene) tilordnet «Sterke sider og utfordringer» er i utgangspunktet (i form) også deskriptive (14 av 14 er konstativer). Men her forankres utdraget som en vurderende tekst gjennom at overskriften signaliserer tilknytning til en bakenforliggende verdistandard. I emnesetningene markeres dette ytterligere ved å sette tilstandsbeskrivelser opp mot ønsker eller mulighetsbeskrivelser gjennom adversativkoplinger («men», «selv om»). Dette skjer i 8 av 14 emnesetninger, for eksempel slik: 
«Norge satser på å utvikle et omfattende system for evaluering og vurdering, men det er foreløpig ufullstendig» (s. 130). Indirekte gir oppstillingen av slike verdivurderinger denne delen av teksten en tydeligere rådgivende funksjon. Opplevelsen av denne funksjonen forsterkes gjennom at flere av de øvrige emnesetningene har innebygde direktiver, for eksempel her: «Norge utvikler en balansert løsning for elevvurdering og må klargjøre formålet med de ulike vurderingsformene» (s. 131). Eksempelet kan tolkes enten som en additivkopling der direktivleddet får en mer selvstendig funksjon, eller som en kausalkopling hvor hele emnesetningen fungerer som direktiv med konstativleddet som belegg.

Til slutt signaliserer «Anbefalinger» ikke bare et tydelig utgangspunkt i en standard for verdsetting, men er i formen klart styringsorientert ved at alle de 14 underliggende setningsemnene fungerer som utgangspunkt for direktiver. Disse setningsemnene framstår nesten som retoriske spørsmål rettet mot de underliggende avsnittene ved at samtlige innledes av infinitivsformer som «krever» både subjekter og modale hjelpeverb. Resultatet av «spørsmålet» blir en direktiv, slik for eksempel setningsemnet «Utvikle tydeligere og mer synlige læringsmål og kriterier for vurdering av elevene» (s. 136) kan utfylles med «direktoratet» som subjekt og «burde» som modalt hjelpeverb.

På bakgrunn av disse observasjonene framstår OECD-teksten som sjangerhybrid med både en informerende og en rådgivende funksjon. Den er med andre ord ikke bare beskrivende, men også instruerende og inngår dermed ikke bare i kartlegging og rapportering (evaluering) som sosial praksis, men også i styring som sosial praksis.

\section{Diskurser som meningsmåte}

Analysen konsentreres her om teksten under overskriften «Anbefalinger» (s. 136-141). Avgrensningen er basert på en antakelse om at OECDs 
premissgivende språkbruk tydeligst kommer fram der. Ovenfor har jeg vist hvordan rådgivning, som uttrykk for styring, framstår som en sentral funksjon. Her undersøkes hvordan det som tenkes påvirket, blir framstilt i teksten.

Det er to sentrale referentkjeder i tekstutdraget: vurdering og mål. Den første er klart mest dominerende og refererer til vurdering/evaluering som fenomen eller som handling(er), noe som ikke er overraskende siden overskriften til OECD-rapporten som helhet også inneholder referenten. Det er hele 56 forekomster (anaforisk referanse), der 52 handler om vurdering og kun 4 om evaluering. Bare 3 av forekomstene er verb (ulike tider av «vurdere»). Resten av forekomstene er enten enkle substantiver («vurdering»), sammensatte substantiver (f.eks. «elevvurdering» og «vurderingskriterier») eller større sammensetninger der referenten inngår (f.eks. «formativ vurdering i skolen» og «vurdering for kvalitetsutvikling»). Referentkjeden er altså dominert av nominaliseringer, en skrivemåte som får referenten til å framstå som tilstand(er) istedenfor som prosess(er). Med bakgrunn i kritisk diskursanalyse kan slike metaforisk nominaliserte representasjoner ses som eksempler på ideologiske prosesser som søker å etablere et faktum eller en virkelighet rent språklig (Fairclough, 2003, s. 220). Også den andre sentrale referentkjeden er dominert av nominaliseringer. I tekstutdraget er det 32 forekomster (anaforisk referanse) der måling og mål eller standarder refereres til som fenomen eller som handlinger. Av disse handler 25 mer spesifikt om mål, hvorav kun 4 er handlingsrettet (ulike tider av verbet «måle»). Substantivene er enten enkle (f.eks. «mål» og «måling»), sammensatte (f.eks. «læringsmål» og «målekriterier») eller inngår i større sammensetninger (f.eks. «målinger av læringsutbytte» og «måloppnåelse og progresjon»).

Det er kanskje ikke så oppsiktsvekkende at tekstutdraget etablerer og kommuniserer vurdering og mål som virkelighetstilstander. De er objekter for 
evalueringsrapporten som sådan, og fungerer dermed også som dens begrunnelse. Allerede i dette ligger muligheten til forsterkning av de to fenomenene, ikke minst jo mer dominerende rolle slike rapporter får i den utdanningspolitiske forvaltningspraksis. I denne analysen er det likevel mer interessant å se på hvilken måte disse virkelighetstilstandene knyttes til og avgrenses fra hverandre og andre fenomener eller handlinger som framstilles $i$ teksten. Spesielt interessant blir dette når det gjelder vurdering for læring . Følgende utsagn er sentralt i den sammenhengen:

Vurdering for læring fordrer en fullstendig endring i tenkemåte om samspillet mellom lærere og elever, og hvordan vurderingserfaringer benyttes til å fremme læring, uavhengig av kravene om å måle prestasjoner (s. 137).

Her kombineres de to dominerende referentkjedene gjennom «vurdering for læring». På tross av rent betydningsmessig å ha en klar handlings- eller prosessdimensjon (vurdere for å lære), framstilles vurdering for læring her som fenomen/tilstand. Som eksempel på nominalisering kan dette i seg selv, på samme måten som ovenfor, ses som ideologisk språkarbeid. Retorisk skjer dette gjennom at selve begrepssammensetningen blir et entymem med et underliggende premiss om at læring faktisk skjer ved hjelp av eller gjennom vurdering. Denne retoriske bruken er for øvrig eksemplarisk for måten referenten vurdering koples både til læring og til kvalitet. Her noen flere eksempler fra tekstutdraget: «tilbakemelding for læring», «vurdering for kvalitetsutvikling» og «vurdering av skolens kjerneprosesser».

Et annet sentralt utsagn, som sier noe om forholdet mellom vurdering og mål, kan også trekkes fram i forlengelsen av dette: 
For å gjøre systemet enhetlig er det viktig at læringsmålene man ønsker å oppnå har en sentral plass, og at alle vurderingsaktiviteter rettes inn mot disse målene (s. 136).

Referenten vurdering blir her underordnet referenten mål, noe som kan tolkes som en tilknytning til og et uttrykk for resultat- og målstyringstankegangen innenfor NPM-paradigmet. Fokuset på mål og måling intensiveres ytterligere gjennom også å anføres som løsningen på eventuelle dysfunksjoner som måtte oppstå, for eksempel i forbindelse med nasjonale prøver i skolen:

For å unngå at det undervises til prøvene og at læreplanen innsnevres, bør det benyttes enda flere målekriterier på elevenes prestasjoner når man vurderer måloppnåelse og progresjon (s. 137).

Men en styrking av resultat- og målstyringstenkningen skjer ikke bare gjennom at denne intensiveres, selve virkeområdet utvides også. Uttrykk for slik styring koples ikke bare til lærernes vurdering av elevenes aktiviteter, de gjelder også ved (ekstern) vurdering av lærerne selv:

Undervisningsstandarder er et hovedelement $\mathrm{i}$ ethvert lærervurderingssystem, fordi de bidrar til en felles forståelse av hva undervisningen skal oppnå, og er en pålitelig referanse for å måle lærerkompetanse (s. 138).

Og videre synes dette, i forbindelse med vurdering for læring, også å gjelde for elevenes vurdering av seg selv:

Spesielt har lærere behov for å utvikle kompetanse til å kunne gi spesifikke og detaljerte tilbakemeldinger til elever, og til å arbeide 
med elever slik at de kan utvikle ferdigheter og vaner for vurdering av egen læring (s. 137).

Undersøkelsen av framstillingsmåten i teksten avdekker altså to parallelle bevegelser. Den første kan beskrives som hybridisering, der «vurdering for læring» forener de to dominerende referentkjedene gjennom å skape overbygning ved hjelp av et underforstått rasjonale om hvordan læring faktisk skjer. Videre foregår det en kolonialisering der vurdering likevel underlegges mål. Slik utvider teksten rekkevidden til resultat- og målstyringstankegangen i NPM.

\section{Stil som henvendelsesformer}

Selv om forfatterne kan identifiseres som enkeltpersoner, forutsettes det at det er OECDs offisielle stil som uttrykkes i teksten, og analysen ser dermed bort fra forfatternes stiluttrykk både som akademikergruppe og som enkeltpersoner. Også i det følgende er fokus rettet mot «Anbefalinger» (s. 136-141), basert på en antakelse om at OECDs egen stemme som ekspertorgan tydeligst kommer fram der. Analysen fokuserer på tekstens tiltalemåte og påstandssikkerhet. Selv om begge deler representerer avsenders væremåte i eller gjennom teksten, bidrar slike uttrykk for stil også til å etablere og opprettholde avsenders relasjon til ulike mottakergrupper. Analysen blir dermed også en undersøkelse av hvordan ulike aktører i det norske utdanningssystemet omtales og tiltales i teksten.

På et overordnet nivå er teksten adressert til norske utdanningsmyndigheter, og det finnes også støtte for dette i tekstutdraget ved at 8 av 14 setningsemner (etter utbygging) i seg selv er adressert til Utdanningsdirektoratet som «bestiller». Resten inneholder likevel, direkte eller indirekte, anbefalinger rettet mot aktører på andre nivåer i skolesystemet. Går man inn i hvert enkelt avsnitt, blir det også tydelig av det er flere aktører som adresseres, også i 
tilfeller der setningsemnene indikerer at adressaten er «bestilleren». På det øverste nivået kan det være Norge som helhet som adresseres:

Norge burde prioritere utvikling av klare og tydelige beskrivelser eller profiler av forventninger til hva lærere skal vite og kunne (s. 138).

På det neste nivået adresseres «de nasjonale myndighetene», «Kunnskapsdepartementet» og «direktoratet», men ofte er det slik at «direktoratet» ikke adresseres alene, det skjer sammen med aktører lenger nede i styringshierarkiet²:

Både direktoratet og fylkesmannsembetene bør systematisk måle kommunenes resultater opp mot viktige indikatorer på læringsutbytte. [...] direktoratet kunne samarbeide med KS og skoleeiere om utviklingen av egnet rapporteringsformat (s. 140).

Selv om dette gir direktoratet en pådriverrolle og et overordnet ansvar i utviklingsprosesser, distribueres ansvar samtidig til andre aktører. Det finnes også eksempler på at slike aktører blir gruppert sammen i ulike konstellasjoner:

\footnotetext{
2 De nasjonale myndighetene er her å oppfatte som den sittende regjeringen, der Kunnskapsdepartementet utgjør den administrative enheten som er ansvarlig for utdanningspolitikken med (Utdannings)direktoratet som nasjonalt ekspert- og kontrollorgan. Fylkesmannsembetene fungerer videre som departementet og direktoratets forlengede arm overfor skoleeierne, primært kommunene, med KS som interesseorganisasjon.
} 
Lærervurdering for kvalitetsutvikling bør være en intern prosess gjennomført av avdelingsledere, erfarne kollegaer og skoleleder med fokus på lærerens praksis i klasserommet (s. 138).

Lavere i styringshierarkiet er det helst lærerne som adresseres, enten som profesjonsutøvere:

Lærerne kan bruke denne typen læringsløp eller veikart for å definere de ferdigheter og kunnskaper elevene må mestre på veien til å bli kompetente i de mangesidige læringsutbyttene som utgjør læreplanen. [...] Lærerne må også utvikle sine ferdigheter for å kunne lage sine egne spesifikke mål og kriterier [...] (s. 136).

- eller som profesjonsgruppe:

I tillegg til vurdering for kvalitetsutvikling [...] ville det også være fordelaktig for læreryrket i Norge å ha en mer formell prosess for lærervurdering for å fastslå hva den enkelte lærer har oppnådd på viktige stadier i karrieren (s. 138).

Tekstutdraget oppleves gjennomgående som formelt. Bruken av nominaliseringer i de to dominerende referentkjedene fungerer som eksempel på dette. Videre oppleves formalitet ved at tekstens avsender (OECD) ikke markeres ved hjelp av nærhetsskapende pronomen. Aktørene som tiltales, adresseres heller ikke ved hjelp av pronomen eller andre nærhetsmarkører, men med egennavn eller mer generelle gruppebetegnelser. På denne måten etablerer avsender autoritet og uttrykker distanse. Tiltalemåten er likevel i mange tilfeller aktiv/direkte, noe sitatene ovenfor også fungerer som eksempler på, og tilfellene hvor meddelelsens adressat skjules av passivkonstruksjoner, kan ofte underforstås å være rettet mot direktoratet som bestiller, slik som i dette eksempelet: 
De nasjonale prøvenes rolle bør slås tydelig fast, og prøvene bør kontinuerlig utvikles, revideres og valideres for å sikre at de er egnet til formålet (s. 137).

Men helt entydig er det ikke, for eksempel i utsagn som dette:

Lærerne [...] burde oppmuntres til å utarbeide vurderingskriterier i samarbeid med elevene, slik at de forstår forskjellen mellom kvalitetsnivåene (s. 136).

Her er det mer åpent hvem som tilskrives et ansvar for tiltak, og utsagnet kan også tolkes som en forpliktelse i form av et påbud eller råd til lærerne selv.

Eksempler på mer direkte tiltalemåte og aktiv språkbruk etablerer for øvrig ikke nødvendigvis større nærhet mellom avsender og mottaker, men kan forsterke påbud avsender kommuniserer overfor spesifikke aktører eller aktørgrupper. En undersøkelse av tekstens påstandssikkerhet med fokus på bruk av modale hjelpeverb kan si noe om styrken på denne autoritetsutøvelsen. I tekstutdraget støtter modalitetstypene ofte opp under hverandre. Det skjer for eksempel i passivkonstruksjonene, som allerede er referert til, der uttrykk for grad av sikkerhet knyttet til innholdet i sentrale tekstreferenter indirekte uttrykker nødvendigheten av / styrken på avsenders forventninger overfor ulike aktører. 
Styrken i modale hjelpeverb, både med hensyn til sikkerhet og nødvendighet, kan spennes ut over en skala fra lav til høy (Svennevig, Sandvig \& Vagle, 1995, s. 179, 185). Tabell 1 viser hvordan dette forholder seg i tekstutdraget.

\begin{tabular}{|c|c|c|c|}
\hline \multicolumn{4}{|c|}{ Påstandssikkerhet } \\
\hline \multicolumn{2}{|c|}{ Styrkegrad (verbal beskrivelse) } & \multirow{2}{*}{ Modalitetsmark $\varnothing$ r i tekstutdrag } & \multirow[b]{2}{*}{ Antall forekomster i tekstutdrag } \\
\hline Sikkerhet & Nødvendighet & & \\
\hline \multirow{2}{*}{$\begin{array}{l}\text { Нøy } \\
\text { (sikkert) }\end{array}$} & $\begin{array}{l}\mathbf{H} \varnothing \mathbf{y} \\
\text { (tvang, plikt) }\end{array}$ & $b \varnothing r$ & 19 \\
\hline & (påbud, råd) & $\begin{array}{l}\text { burde } \\
\text { må }\end{array}$ & $\begin{array}{l}11 \\
4\end{array}$ \\
\hline $\begin{array}{l}\text { Middels } \\
\text { (sannsynlig) }\end{array}$ & $\begin{array}{l}\text { Middels } \\
\text { (forventning) }\end{array}$ & vil/ville & 10 \\
\hline \multirow{2}{*}{$\begin{array}{l}\text { Lav } \\
\text { (mulig) }\end{array}$} & (Iøfte) & kan & 20 \\
\hline & $\begin{array}{l}\text { Lav } \\
\text { (ønske) }\end{array}$ & kunne & 16 \\
\hline
\end{tabular}

Tabell 1: Fordeling av ulike modale typer hjelpeverb etter styrkegrad

Til sammen er det $34(19+11+4)$ «bør»/ /burde»/ «må», noe som uttrykker enten høy sikkerhet eller påbud/råd. Samtidig er det til sammen $36(20+16)$ «kan» og «kunne», noe som uttrykker enten lav sikkerhet (mulighet) eller kun en tillatelse eller et ønske. I midten av skalaen er det langt færre forekomster (10) med «vil»/ «ville», som uttrykk for sannsynlighet eller forventning. På et overordnet nivå er det dermed tilsynelatende balanse mellom høy og lav påstandssikkerhet i det aktuelle tekstutdraget.

En undersøkelse av tilfeller der aktivkonstruksjoner kopler modalitetsmarkører til konkrete aktører, noe som skjer i en tredjedel av forekomstene (26/80), nyanserer bildet. Tabell 2 viser her en generell tendens til sterkere (15/26 «høy påstandssikkerhet») enn til svakere autoritetsutøvelse (11/26 «lav påstandssikkerhet») overfor aktørene. 


\begin{tabular}{|l|l|l|l|l|}
\hline \multicolumn{1}{|c|}{$\begin{array}{c}\text { Antall modalitetsmarkører } \\
\text { (modale hjelpeverb) }\end{array}$} & \multicolumn{3}{c|}{ Styrkegrad } \\
\cline { 2 - 6 } & $\begin{array}{l}\text { Lav } \\
\text { påstandssikkerhet }\end{array}$ & $\begin{array}{l}\text { Moderat } \\
\text { påstandssikkerhet }\end{array}$ & $\begin{array}{l}\text { Høy } \\
\text { påstandssikkerhet }\end{array}$ & Alle \\
\hline Alle forekomster & 36 & 10 & 34 & 80 \\
\hline $\begin{array}{l}\text { I aktivkonstruksjoner relatert } \\
\text { til alle aktører }\end{array}$ & 11 & 0 & 15 & 26 \\
\hline $\begin{array}{l}\text { I aktivkonstruksjoner relatert } \\
\text { til «rapportbestillere» }\end{array}$ & 6 & 0 & 9 & 15 \\
\hline $\begin{array}{l}\text { I aktivkonstruksjoner relatert } \\
\text { til «andre aktører» }\end{array}$ & 5 & 0 & 6 & 11 \\
\hline
\end{tabular}

Tabell 2: Forekomster av modale hjelpeverb i aktivkonstruksjoner, fordelt etter styrkegrad

Om Utdanningsdirektoratet og de nasjonale myndighetene (rapportbestillerne) isoleres som egen gruppe, ser vi videre at de utgjør flertallet av konstruksjonene (15/26 «rapportbestillere» versus 11/26 «andre aktører»). Mønsteret gjenspeiler for øvrig passivkonstruksjonene nevnt ovenfor, som ofte kan underforstås som rettet mot rapportbestillerne. Men disse funnene betyr ikke nødvendigvis at autoritetsutøvelsen også er sterkere overfor denne gruppen. En sammenlikning av gruppene «rapportbestillere» og «andre aktører» med hensyn til lav (6 versus 5) og høy (9 versus 6) påstandssikkerhet viser at forskjellen ikke er signifikant forskjell ( $\mathrm{p}=0,781 \mathrm{i}$ khikvadrattest).

Hva skjer så om man undersøker hvordan grad av påstandssikkerhet relateres til tekstreferenter som kan tolkes som uttrykk for henholdsvis pedagogisk praksis og for utdanningspolitisk forvaltningspraksis? Dette gir et annet fokus enn aktørperspektivet (aktivkonstruksjonene) i tabell 2. Tabell 3 gir en oversikt over tilfellene der de modale hjelpeverbene slik koples til pedagogiske eller administrative aktiviteter, noe som er tilfellet for halvparten av 
forekomstene (39/80). Ofte utgjør referentkjedene vurdering/evaluering, mål (og resultat) en komponent i disse, men ikke med nødvendighet.

\begin{tabular}{|l|l|l|l|l|}
\hline \multicolumn{1}{|c|}{$\begin{array}{c}\text { Antall modalitetsmarkører } \\
\text { (modale hjelpeverb) }\end{array}$} & \multicolumn{3}{c|}{ Styrkegrad } \\
\cline { 2 - 6 } & $\begin{array}{l}\text { Lav } \\
\text { påstandssikkerhet }\end{array}$ & $\begin{array}{l}\text { Moderat } \\
\text { påstandssikkerhet }\end{array}$ & $\begin{array}{l}\text { Høy } \\
\text { påstandssikkerhet }\end{array}$ & Alle \\
\hline Alle forekomster & 36 & 10 & 34 & 80 \\
\hline $\begin{array}{l}\text { Pedagogisk praksis + utdannings- } \\
\text { politisk forvaltningspraksis }\end{array}$ & 20 & 0 & 19 & 39 \\
\hline $\begin{array}{l}\text { Utdanningspolitisk } \\
\text { forvaltningspraksis }\end{array}$ & 15 & 0 & 7 & 22 \\
\hline Pedagogisk praksis & 5 & 0 & 12 & 17 \\
\hline
\end{tabular}

Tabell 3: Forekomster av modale hjelpeverb relatert til ulike type praksis, fordelt etter styrkegrad

I likhet med det overordnede nivået er det også med denne lesemåten balanse mellom høy og lav påstandssikkerhet (19 versus 20). De modale hjelpeverbene framstår videre som noe mer koplet til utdanningspolitisk forvaltningspraksis (22/39 forekomster), som rapportbestillerne primært inngår i, enn til pedagogisk praksis, men ikke mer markant enn forekomsten av modale hjelpeverb i aktivkonstruksjoner spesifikt relatert til denne gruppen (15/26 forekomster i tabell 2). Derimot viser tabell 3 et interessant mønster i fordelingen av modalitetsmarkørene når disse knyttes til de to ulike praksisene. Påstandssikkerheten er ofte høy (12 av 17 forekomster) der innholdet dreier seg om elevers læring eller lærernes pedagogiske praksis, slik som i disse utsagnene:

Lærerne må også utvikle ferdigheter for å kunne lage sine egne spesifikke mål og kriterier, og burde oppmuntres til å utarbeide vurderingskriterier i samarbeid med elevene, slik at de forstår forskjellen mellom kvalitetsnivåene (s. 136). 
Meningsfull lærervurdering burde ha til hensikt å oppnå lærerutvikling og forbedring av undervisning og læringsprosesser (s. 138).

Videre er påstandssikkerheten ofte lav (15 av 22 forekomster) i utsagn der innholdet kan koples til ulike former for styrings- eller ledelsesaktiviteter, slik som i disse utsagnene:

Avansement i lærerkarrieren kunne organiseres gjennom et system med registrering eller sertifisering av lærerne på viktige stadier i karrieren (s. 139).

Grundig tilsyn med kommunale resultater kan brukes til å undersøke bekymringsfulle nivåer og eksempler på forbedringer (s. 140).

En sammenlikning av «pedagogisk praksis» og «utdanningspolitisk forvaltningspraksis» med hensyn til lav og høy påstandssikkerhet viser at forskjellen er signifikant ( $\mathrm{p}=0,016 \mathrm{i}$ khikvadrattest). Samlet tyder dette på at autoritetsutøvelsen er sterkere når det gjelder spørsmål om pedagogiske tiltak enn i spørsmål rettet mot styringens praksisfelt.

\section{Oppsummering av analysen}

Analysen av stildimensjonen supplerer funn i undersøkelsene både av sjangerog diskurser. På et mer overordnet nivå flytter først analysen av sjangerdimensjonen teksten fra evalueringens til styringens praksisfelt. Videre identifiserer analysen av diskursdimensjonen to parallelle bevegelser som gjør at tekstutdraget utvider rekkevidden av resultat- og målstyringstankegangen i NPM til også å gjelde pedagogisk praksis. Analysen av stil avdekker så til slutt også to parallelle bevegelser: Tiltalemåten viser hvordan tekstutdraget 
posisjonerer avsender slik at det etableres et grunnlag for autoritetsutøvelse ikke bare overfor «bestiller», men også overfor andre aktørgrupper. Påstandssikkerheten avdekker så at denne autoritetsutøvelsen realiseres gjennom tydeligst å adressere pedagogisk praksis, noe som i sin tur innebærer både fokusering og intensivering av resultat- og målstyringstankegangen. Samlet viser analysen dermed hvordan og med hvilken kraft teksten fungerer innenfor skolesystemet, ikke bare som del av evaluerings- og styringspraksis, men også innenfor det pedagogiske praksisfeltet.

\section{Diskusjon}

Spørsmålene som stilles til empirien i denne artikkelen, handler om hvordan mulige gevinster ved evaluering/vurdering framstilles, og om hvorvidt tekstutdragets rekkevidde og utøvelse av autoritet primært omfatter styringspraksis eller den pedagogiske praksis. Analysen har vist hvilken nøkkelrolle vurdering for læring spiller i denne sammenhengen. Vurdering for læring framstår som en mulighet skolen har for å legitimere sin virksomhet, men kan denne «gaven» også vise seg som trojansk hest?

Vurdering for læring «åpner» skolens vurderingspraksis for resultat- og målstyringstankegangen, som på denne måten får utvidet rekkevidde. Samtidig flyttes ansvarliggjøringens fokus fra utdanningspolitisk forvaltningspraksis til pedagogisk praksis, hvor det også skjer en intensivering av autoritetsutøvelsen. Begge deler kan med henvisning til Fairclough omtales som varianter av rekontekstualisering (Chouliaraki \& Fairclough, 1999) og ses som eksempler på ideologisk arbeid i teksten. Det vil si en utnyttelse av språklig makt som avgrenser tolkningsmulighetene og dermed også har potensial til å begrense handlingsrommet til aktørene som er involvert i den pedagogiske praksis ved at denne underlegges en ny logikk (Skrede, 2017, s. 55). Denne logikken kan i sin rendyrkede form omtales som vurdering som læring, der fokuset på mål og resultat i seg selv framstår som kritisk 
prosesskvalitet i læringsarbeidet. For ansvarsstiller fungerer denne framgangsmåten i sin tur som en ny mulighet i bruken av styringsvirkemidler, lik Odyssevs' krigere klatrer ut av hesten, åpner portene og hærtar Troja i ly av mørket. Det skjer ved at man slik på en legitim måte innfører resultatbasert ansvarliggjøring uten å utfordre accountability-biaset, med den provoserende maktutøvelsen det i tilfelle kunne medført overfor profesjonsgruppene. Den avsluttende drøftingen av evalueringsteksters funksjon i styring av og for læringsaktiviteter i dagens skole, konsentreres om i hvilken grad aktørene i skolen er bundet opp av denne situasjonen.

Basil Bernsteins (1996) begrep «pedagogic device» kan bidra til å kaste lys over påvirkningen utdanningspolitisk forvaltningspraksis og pedagogisk praksis øver på hverandre. Oversatt til Bernsteins terminologi kan henholdsvis «regulerende» og «instruerende diskurs» benyttes som merkelapper på disse. Det analysen så langt har gjort, kan da beskrives med Haley Woodside-Jiron (2004, s. 176):

By placing these discourses in detailed relation to one another and examine how the regulative discourse actually shapes the instructional discourse, we begin to understand the pedagogic device or specific power relations between the two.

Woodside-Jiron analyserer literacy-reformer i kaliforniske skoler med utgangspunkt i en slik fortolkningsramme. Mye kan tyde på at dette også skjer i sammenheng med det nye fokuset på vurdering for læring i norsk skole. Man kan da hevde at forskningspraksis fungerer som pedagogic device som legitimerer maktutøvelse overfor den pedagogiske praksis. Maktutøvelsen materialiseres så nettopp gjennom forskjellige former for evalueringstekster på ulike nivåer i skolesystemet, slik også den analyserte teksten er eksempel på. 
På den annen side åpner perspektivet som anlegges gjennom KDA, for at påvirkningen mellom ulike praksiser likevel ikke er så ensrettet. Selv om resultat- og målstyringstankegangen, også i seg selv, synes å forutsette en påvirkningsretning der sentrale styringspådriv forgrener seg i skolesystemet, trenger disse i første omgang ikke nødvendigvis å få konsekvenser utover administrative tiltak og prioriteringer. Når tankegangen likevel synes å oppnå så gjennomgripende effekt, også i den pedagogiske praksis, kan dette skyldes at tekster brukt til vurdering av elevers ulike kapasiteter allerede har en lang historie i skolen, og at disse over tid og i takt med både kulturelle og teknologiske endringer har utviklet og fornyet sitt uttrykk. I videre forstand betyr dette at evalueringstekster fungerer som «fysiske eller intellektuelle redskaper som er utviklet innenfor en kultur, og som former menneskenes forståelse av og samspill med objektene omkring seg» (Säljö, 2005, s. 27). De viser allerede både skoleledere, lærere og elever hvordan læring i skolen skal forstås og hvilke aktiviteter læringen kan inngå i, samtidig som de legitimerer skolens aktiviteter overfor ulike interessentgrupper, både elevenes foresatte og de bevilgende myndigheter.

Den sosiale strukturen er altså klargjort, men betyr det at motstanden alt er nedkjempet? Det kampen står om, er den sosiale praksisen knyttet til evalueringstekster, eller med andre ord hvor absolutterende funksjon disse tekstene, og dermed også resultat- og målstyringen, skal få i skolen. Vurdering av læring, vurdering for læring og vurdering som læring kan også i denne sammenhengen uttrykke i hvor stor grad dette skjer. En pedagogisk praksis kjennetegnet av vurdering for læring krever et kontinuerlig fokus på mål og resultat som gir elever og lærere liten frihet til å framelske andre dimensjoner ved det komplekse læringsarbeidet. Dette står i motsetning til vurdering av læring, som tross autoritetsutøvelsen fyller mer avgrensede tidsrom, og som gir både elever og lærere større frihet i utøvelsen av aktiviteter mellom vurderingspunktene. I denne sammenhengen representerer vurdering som læring den mest absolutterende funksjonen med 
et innebygd rasjonale om at det er gjennom kontinuerlig vurdering, gjennomført av både lærere og elever, at læring i det hele tatt skjer og skolens legitimitet kan sikres. Det interessante spørsmålet er da hvor langt aktørene i skolens pedagogiske praksis faktisk må strekke seg i retning av vurdering som læring for å legitimere egen virksomhet og aktivitet overfor ulike interessentgrupper.

\section{Konklusjon}

Interessentgruppen i fokus for denne undersøkelsen er å finne i den utdanningspolitiske forvaltningspraksis, som analysen har vist øver et styringspådriv rettet mot den pedagogiske praksis - et styringspådriv som igjen henter mye av sin legitimitet i forskningspraksis. Enn så lenge synes vurdering av læring fortsatt å kunne bidra til å gi aktørene i skolen legitimitet til å bevare et relativt stort handlingsrom i utøvelsen av sin pedagogiske praksis, og de bør ikke uten videre gi fra seg dette handlingsrommet ved å gjøre vurdering for læring til dominerende pedagogisk rasjonale.

En praksis som i liten grad er hensyntatt i denne undersøkelsen, er representert ved skoleelevenes foresatte som interessentgruppe. Hvilken indirekte påvirkning eller styringspådriv som rettes mot skolens pedagogiske virksomhet gjennom evalueringstekster og informasjonsmateriell som griper inn i foreldregruppens praksis, vil være et interessant område for videre utforskning. Dersom også slike tekster viser seg å materialisere den samme resultat- og målstyringstankegangen som analysen i denne artikkelen har avdekket, utsettes den pedagogiske praksis for en kryssild som i sterkere grad avgrenser handlingsrommet til skolens aktører. 


\section{Referanser}

Behn, R.D (2001). Rethinking democratic accountability. Washington, D.C: Brookings Institution Press.

Bernstein, B. (1996). Pedagogic symbolic control and identity: Theory, research, critique. Bristol, PA: Taylor \& Francis.

Black, P., Harrison, P., Lee, C., Marshall, B. \& Wiliam, D. (2004). Working inside the black box: Assessment for learning in the classroom. Phi Delta Kappan, 86(1), 8-21.

Black, P. \& Wiliam, D. (1998). Inside the black box: Raising standards through classroom assessment. Phi Delta Kappan, 8o(2), 139-148.

Burke, J.C. (2005). Achieving accountability in higher education: Balancing public, academic, and market demands. San Francisco: Jossey-Bass

Campbell, D.T. (1976). Assessing the impact of planned social change.

Occational papers series 8. Kalamazoo, MI: Western Michigan University. Hentet fra

http://citeseerx.ist.psu.edu/viewdoc/download?doi=10.1.1.170.6988\&rep=rep $\underline{1 \& \text { type }=\text { pdf }}$

Chouliaraki, L. \& Fairclough, N. (1999). Discourse in late modernity: Rethinking Critical Discourse Analysis. Edinburgh: Edinburgh University Press

Eggen, A.B. (2007). Vurderingskompetanse og definisjonsmakt. Norsk Pedagogisk Tidsskrift, 91(1), 150-164. 
Elstad, E. (2010). PISA i norsk offentlighet: Politisk teknologi for styring og bebreidelsesmanøvrering. I E. Elstad \& k. Sivesind (red.), PISA: Sannheten om skolen? (s. 100-121). Oslo: Universitetsforlaget.

Engh, R. (2011). Vurdering for læring i skolen: På vei mot en bærekraftig vurderingskultur. Kristiansand: Høyskoleforlaget

Fairclough, N. (2003). Analysing discourse: Textual analysis for social research. London: Routledge.

Halliday, M.A.K. (2004). An introduction to functional grammar (3. utg., revidert av Christian M.I.M Matthiessen). London: Arnold.

Hattie, J. \& Timperley, H. (2007). The power of feedback. Review of Educational Research, 77(1), 81-112.

Hood, C. (2002). The risk game and the blame game. Government and opposition, $7(1), 15-37$.

Kirke-, utdannings- og forskningsdepartementet. (1991). Om organisering og styring i utdanningssektoren (St.meld. nr. 37 (1990-1991)). Hentet fra https://www.stortinget.no/no/Saker-ogpublikasjoner/Stortingsforhandlinger/Lesevisning/?p=199091\&paid=3\&wid=c\&psid=DIVL402\&s $=$ True

Langfeldt, G. \& Birkeland, N.R. (2010). PISA i lys av styringsteori. I E. Elstad \& K. Sivesind (red.), PISA: Sannheten om skolen? (s. 83-99). Oslo: Universitetsforlaget.

Langfeldt, G., Elstad, E. \& Hopmann, S. (2008). Ansvarlighet $i$ skolen: Politiske spørsmål og pedagogiske svar - resultater fra forskningsprosjektet "Achieving School Accountability in Practice". Oslo: Cappelen Akademisk. 
NOU 1988:22. (1988). Med viten og vilje. Oslo: Utdannings- og forskningsdepartementet.

NOU 2002:10. (2002). Førsteklasses fra første klasse. Oslo: Utdannings- og forskningsdepartementet.

NOU 2003:16. (2003). I første rekke: Forsterket kvalitet i en grunnopplæring for alle. Oslo: Utdannings- og forskningsdepartementet.

Nusche, D., Earl, L., Maxwell, W. \& Shewbridge, C. (2012). OECDs gjennomgang av evaluering og vurdering innen utdanning: Norge. doi: http://dx.doi.org/10.1787/9789264196735-no

Searle, J.R. (1969). Speech acts: An essay in the philosophy of language. Cambridge: Cambridge University Press.

Skrede, J. (2017). Kritisk diskursanalyse. Oslo: Cappelen Damm.

Svennevig, J., Sandvig, M. \& Vagle, W. (1995). Tilnærminger til tekst: Modeller for språklig tekstanalyse. LNUs skriftserie 89. Oslo: Cappelen Akademisk.

Säljö, R. (2005). Lärande och kulturella redskap: Om lärprocesser och det kollektiva minnet. Stockholm: Norstedts Akademiska Förlag.

Utdannings- og forskningsdepartementet. (1990). Studiekvalitet: Kortversjon av innstilling fra studiekvalitetsutvalget. Bergen: Døves trykkeri.

Utdannings- og forskningsdepartementet. (2004). Kultur for læring (St.meld. nr. 30 (2003-2004)). Hentet fra https://www.regjeringen.no/no/dokumenter/stmeld-nr-030-2003-2004/id404433/ 
Woodside-Jiron, H. (2004) Language, power, and participation: Using Critical Discourse Analysis to make sense of public policy. I R. Rogers (red.), $A n$ introduction to Critical Discourse Analysis in education (s. 173-205). London: Lawrence Erlbaum. 